\title{
The influence of selected ingredients of dietary supplements on skin condition
}

\author{
Barbara Szyszkowska1', Celina Łepecka-Klusek¹, Katarzyna Kozłowicz², Iwona Jazienicka², Dorota Krasowska ${ }^{3}$
}

${ }^{1}$ Department and Clinic of Gynecology and Gynecological Endocrinology, Medical University of Lublin, Poland Head of Department: Prof. Lechosław Putowski MD, PhD

${ }^{2}$ Laboratory of Cosmetology and Aesthetic Medicine, Medical University of Lublin, Poland

Head of Laboratory: Iwona Jazienicka MD, PhD

${ }^{3}$ Department of Dermatology, Venereology and Paediatric Dermatology, Medical University of Lublin, Poland

Head of Department: Prof. Grażyna Chodorowska MD, PhD

Postep Derm Alergol 2014; XXXI, 3: 174-181

DOI: $10.5114 /$ pdia.2014.40919

\begin{abstract}
Introduction and aim of the article. Healthy skin is an excellent barrier maintaining balance between the internal and external environment of the body. Because it is constantly changing as a result of, on the one hand, environmental factors and, on the other hand, the process associated with skin aging, it requires many nutrients and minerals that help maintain its homeostasis. The aim of this dissertation is to discuss the most commonly used ingredients in dietary supplements that improve the appearance and quality of the skin. Brief description of the state of the art. Quick pace of life, unbalanced diet and stress make it impossible to provide all the necessary components, which affects the proper functioning of the skin. That is why, the interest in dietary supplements as products that help to reduce the deficiencies of individual components is increasing. Supplements that affect the skin, hair and nails mainly consist of: vitamins C, E, A, B-vitamins, micro- and macronutrients and fatty acids. In this paper, some of the ingredients of skin affecting dietary supplements are discussed. A varied and proper diet should provide all the nutrients necessary for the correct functioning of the body. Dietary supplements are intended to supplement the normal daily food intake of nutrients which are not supplied with food in a sufficient quantity. Therefore, their use becomes relevant.
\end{abstract}

Key words: dietary supplements, nutraceuticals, nutricosmetics, skin, diet.

\section{Introduction}

Proper nutrition is a direct factor affecting well-being, health and proper skin condition. The human skin is subject to constant change, which is why dietary supplements can complement the normal diet by providing properly balanced nutrients [1]. The concept of a normal diet should be understood as a customary diet consisting of traditional foods. Therefore, it must contain a variety of ingredients, that is vegetables, fruits, whole grains, legume products, dairy products, fish and lean meat. Diet should provide all the nutrients in quantities that meet established and recommended standards, which are based on generally accepted data. Survey results indicate, however, that the diets of the European Union population do not satisfy the requirements for all nutrients. Therefore, there appeared an increased demand for creating a new kind of food products, which are intend- ed to supplement the diet with the necessary nutrients. Beyond the nutritional value, functional foods contain health-promoting components with proven beneficial effects on one or more functions of the organism. They improve health and well-being and/or reduce the risk of developing numerous diseases [2]. It should be borne in mind that an excessive intake of vitamins and minerals can cause adverse health effects [3].

In Western Europe and the U.S. the market for functional foods, which also includes supplements, has been operating for a significant period of time. In Poland the term "dietary supplement" has appeared recently [4].

A dietary supplement is a consumable product, which aims at supplementing the normal diet. It constitutes a concentrated source of vitamins or minerals, or other substances with a nutritional or other effect [5]. In many cases, the use of dietary supplements is an action justi-

Address for correspondence: Barbara Szyszkowska MD, Department and Clinic of Gynecology and Gynecological Endocrinology, Medical University of Lublin, First Military Hospital with Non-Public Health Care Institution, 23 Racławickie Ar., 20-049 Lublin, Poland, phone: +48 516167 622, e-mail: b.dzygadlo@op.pl

Received: 22.04.2013, accepted: 23.05.2013. 
Table 1. The classification of dietary supplements, except vitamins and minerals (prepared by the authors)

\begin{tabular}{ll}
\hline Dietary supplements & Example substances \\
\hline Amino acids & L-arginine \\
\hline Enzymes & Lactase \\
& Papain \\
\hline Prebiotics and probiotics & Inulin \\
& Lactobacillus acidophilus \\
& Bifidobacterium species \\
& Yeast \\
\hline Essential non-saturated fatty acids & -Linolenic acid \\
& Fish oil (DHA/EPA) \\
& Flaxseed oil (Linum usitatissimum) \\
& Borage seed oil (Borago officinalis) \\
\hline Plant-origin ingredients & Aloe (Aloe vera) \\
& Ginkgo (Ginkgo biloba) \\
& Ginseng (Panax ginseng) \\
& Garlic (Allium sativum) \\
& Green tea extract (Camellia sinensis) \\
& Garcinia cambogia extract \\
& Guarana Extract (Paullinia cupana) \\
\hline Other substances: & Lycopene \\
& Lutein \\
& Coenzyme Q10 \\
& Taurine \\
Carnitine \\
Inositol \\
Glucosamine \\
Chitosan \\
Spirulina \\
Soy isoflavones \\
\hline
\end{tabular}

fied and recommended by experts. This applies to people who demonstrate a shortage of nutrients in the organism due to a disease or other physiological condition that prevents proper coverage of individual components $[6,7]$. Currently, in Poland there has been an increase in the popularity of consumption of dietary supplements in a variety of social groups $[8,9]$. It is often associated with the opinion that due to the food processing technology, food products are devoid of nutrients; but there exists also a large group of people who want to improve the appearance of their skin, nails or hair [10].

No specific regulations regarding the ingredients of dietary supplements, other than vitamins and minerals, make the market of these products considerably diversified [11]. According to a report of the European Commission [12], the number of substances used in the manufacture process of dietary supplements is about 400; $50 \%$ of the dietary supplement market in the European Union are vitamins and minerals. In addition to vitamins and minerals, other supplements can be classified in six categories [12] (Table 1).

Bearing in mind both benefits and possible side effects of dietary supplementation, the decision to start treatment with the use of these products should be preceded by consultation with a specialist - a doctor or a nutritionist. The time of the treatment should be limited until the resolution of identified deficiencies [13].

\section{Aim}

The aim of the study is to analyze the most commonly used ingredients in food supplements, which improve the appearance and quality of the skin.

A group of dietary supplements which is developed for beauty care is called nutricosmetics or nutraceuticals. These are individual diet components, as well as additives, food products and dietary supplements, the consumption of which provides greater health benefits than those resulting from the diet [14]. They include, in particular, vitamins A, E, C and group B vitamins, horsetail, iron, copper, phosphorus, L-methionine, manganese, borage seed oil and eicosapentaenoic acid (EPA) and docosahexaenoic acid (DHA) acids [15]. On the other hand, in the products for hair and nails, zinc, silicon and calcium are additionally present. Supplements also include neutralizers of free radicals, thereby slowing the aging process. In addition to vitamins $\mathrm{E}$ and $\mathrm{C}$ those are, for example carotenoids, flavonoids, lycopene and coenzyme Q10. Preparations that are designed to improve skin firmness and reduce cellulite include, among others, substances 
which enhance collagen and elastin fibers, such as isoflavones (called phytoestrogens) that mimic the action of estrogen, female sex hormones. Nutricosmetics and other dietary supplements' manufacturers ensure their high efficiency. However, before using supplements, it is advised to read components of the product. It is worth noting that some dietary supplements were named as such only to enhance their attractiveness. One should turn one's attention to the information if the effectiveness of the medicament is confirmed in clinical trials because they are to distinguish nutricosmetic products from other dietary supplements [16].

\section{Flavonoids}

Phytoestrogens are plant compounds having similar effects to estrogen. In dietary supplements, isoflavones are mainly used. They are derived mainly from soybeans and other legumes, lignans (found in flaxseed oil) and coumestans found in sunflower seeds and bean sprouts [16]. Flavonoids (polyphenols), including phytoestrogens, are increasingly used in menopause to delay the signs of skin aging. It was also shown that the use of phytoestrogens has a beneficial effect on the serum lipid profile. It is thought that they reduce the risk of cardiovascular diseases in postmenopausal women. Furthermore, these compounds positively affect bone metabolism, mucous membranes and skin; also effectively relieve menopausal symptoms [17-19].

\section{Coenzyme Q10}

Another compound with strong antioxidant properties is coenzyme Q10 or ubiquinone. It is a widely distributed system in nature, hence its name - that is Ubitarius meaning ubiquitous. It occurs both in animal and plant worlds and among microorganisms. This compound is found in every living cell of an organism. It plays an important role in the mitochondria, where during the oxygen combustion process energy is formed. The body aging process is a result of mitochondrial damage caused by free radicals. This can lead to a significant impairment of the heart muscle, brain, and liver [20]. Too small concentration of ubiquinone may initially manifest itself as a chronic fatigue syndrome, then lead to the dysfunction of the organs affected by its shortage. Coenzyme Q10 activates defense mechanisms, protects body cells from oxidation, and stimulates metabolism and regeneration. It accelerates cell renewal and delays the aging process. Due to its characteristics it is often referred to as the elixir of youth [4].

\section{Probiotics}

Clinical studies have demonstrated beneficial effects of probiotics in diseases of the gastrointestinal tract (irritable bowel syndrome, inflammatory bowel disease, diarrhea) and allergic diseases (atopic dermatitis). They also show an increased resistance of the immune system (immunomodulation) [21].

Atopic dermatitis (AD) is a chronic, recurrent inflammatory dermatosis. This disease is characterized by lesions of a typical location of eczema and pruritus. AD pathogenesis is not fully discovered. An important role in eliciting changes in AD plays exposure to external and environmental factors. These factors stimulate the immune system to allergic response [22, 23]. Research on the use of probiotics in the prevention and treatment of atopic dermatitis was conducted by independent research centers, including a Finnish team and a Czech team. The Finnish group gave young children allergic to proteins of cow milk, protein hydrolysates containing strain $L b$. rhamnosus GG. The results were presented on a SCORAD (Scoring Atopic Dermatitis - atopic dermatitis severity index) scale. SCORAD index reduction was observed in the group receiving probiotics for 1 month. Strains of Lactobacillus rhamnosus GG and Bifidobacterium animalis subsp. lactis Bb-12 were administered in compounds of protein hydrolysates. After 2 months, the SCORAD index was reduced in both groups compared to the control group. These studies have contributed to the increased interest in probiotics for the treatment of $A D$ $[24,25]$. In other studies, Lactobacillus rhamnosus GG was given to pregnant women with a history of atopic dermatitis, once a day for 2 to 4 weeks before delivery. After delivery, the probiotic was still administered to both mother and child over a period of about 6 weeks. The study, which was randomized, was conducted with placebo-controlled and double-control sample, including 159 women and infants. The effect of probiotics on the incidence of allergy was assessed after 2 and 4 years. In the second year of life in the group taking probiotics, AD occurred twice less often compared to children taking placebo. In the fourth year of life, the incidence of AD in the population treated with probiotics remained reduced. The disease was diagnosed in $47 \%$ of children in the control group, compared to $26 \%$ of children receiving the probiotic $[26,27]$.

\section{Horsetail}

Horsetail has an antibacterial, remineralizing and regenerating effect. It is a rich source of flavonoids, potassium, and silicon. Large amounts of these components are necessary for the proper functioning of rapidly growing tissues: epidermis, hair and nails [16]. The level of silicon in the body decreases with age, which results in nail and hair brittleness and decreased resistance to fungal and bacterial infections. It participates in the biosynthesis of collagen, which is the main component of connective tissue. In addition, it strengthens the walls of blood vessels, which become more flexible, reducing their permeability and accelerating the wound healing process [28]. 


\section{Aloe}

Aloe vera is used to treat a number of diseases, including dermatological disorders, as well as in the production of cosmetics. Aloe vera gel, extracted from the pulp of the leaf, is used both internally and externally as a topical anti-inflammatory agent and accelerant of wound and burn healing [16]. It has been shown that aloe gel reduces blood glucose levels in diabetic patients, reduces lipid levels in patients with hyperlipidemia, and inhibits the secretion of pepsin and hydrochloric acid, which prevents formation of stomach ulcers [29]. Clinical studies have proven that aloe vera gel significantly reduces wrinkles, increases skin elasticity and procollagen production [30]. The use of extracts from aloe vera helps to maintain proper skin hydration, and may be effective in the treatment of dry skin [31].

The use of aloe sensitizes to UV radiation. Therefore, after exposure to UV inflammatory reactions of the skin and permanent discoloration may occur. There may also appear other side effects: nausea, dizziness and headaches, tingling in the ears, high blood pressure, insomnia, memory loss, rashes, and more. Toxic effects of aloe vera on the liver have been documented, causing inflammation, which resolved after discontinuation of oral aloe vera preparations [29].

\section{Tea tree oil}

Tea tree oil (Melaleuca alternifolia) is a very commonly used ingredient in cosmetics for oily skin. It indicates a very broad spectrum of antimicrobial activity and acts anti-inflammatory. The distinctive smell of tea tree oil can be eliminated by encapsulating in cyclodextrin, which may also cause a slower release of the essential oil (up to 12 h) [32]. Rosalina oil (Rosalina Oil Australia) can also be used. It may be known as the oil of lavender tea tree (Melaleuca ericifolia), which has similar properties to tea tree oil. The advantage of lavender oil tea tree is its fresh, floral scent of lavender. The main component of this oil, similarly to the tea tree oil, is linalool. Leptospermum scoparium (a tea tree from New Zealand) - manuka belongs to the myrtle plant family (Myrtaceae). Numerous varieties of this species are known for their healing properties. Manuka bush may be found in Australia, New Zealand and the surrounding islands. Thanks to the antibacterial properties of manuka oil and manuka bush water-soluble extract it is considered a suitable raw material used in sensitive and oily skin cosmetics. Also, honey derived from the manuka bush flowers can be used for facial skin care. Currently in Australia, a manuka honey extract (Leptospermum) is produced that can function as a cosmetic raw material. Manuka honey affects the osmotic pressure, which allows for maintaining the skin's water balance, inhibiting the growth of microorganisms. Manuka honey extract is a very good resource for combination skin care [32-34].

\section{Vitamin E}

Because of its strong antioxidant properties, vitamin $E$ is considered to be one of the main compounds that protect the body against oxidative stress. It may participate in the first line of defense against reactive forms of oxygen species (ROS) efficiently quenching singlet oxygen. Thus, it does not react with polyunsaturated fatty acids residue, which exists in phospholipids of cell membranes. Moreover, the reactions of lipid peroxidation and free radicals generation are inhibited [35]. In the second line of defense, vitamin $\mathrm{E}$ reacts with lipid peroxide free radicals, inactivating them and inhibiting both their production and the string of their chain reactions that damage the cells [35-43]. Preventing the oxidation of polyunsaturated fatty acids, vitamin E substantially prevents the development of atherosclerosis. It also stimulates the synthesis of antithrombotic substances, reducing the risk of microthrombus. Moreover, it provides adequate stability and permeability of cell membranes and prevents macrocytic anemia in children. Vitamin $\mathrm{E}$ also protects red blood cells during their transportation of oxygen. Supporting the process of cellular respiration it affects the proper functioning and maintenance of high muscle efficiency. That is why athletes are recommended to consume products that contain a substantial amount of vitamin E. It is also essential for proper sperm production in men $[39,44]$. Vitamin E deficiency may create keratoses and premature skin aging, difficulty in wound healing, impaired ability to concentrate, irritability and impaired fertility [35].

\section{Vitamin C}

Vitamin $C$ is the main antioxidant of aquatic organisms. It is an essential cofactor in numerous processes of systemic biosynthesis. As a substance transferring electrons, it participates in metabolic processes. Moreover, it contributes to the biosynthesis of collagen, accelerates wound healing, bedsore healing and setting bones. It participates in the metabolism of fats, cholesterol and bile acids. Vitamin $C$ is involved in the biosynthesis of adrenal hormones. It facilitates the absorption of non-haem iron and participates in erythropoiesis [35]. In addition, the immune-stimulating properties of vitamin $C$ and its bacteriostatic properties are stressed [43, 45-48]. In addition, vitamin C affects the skin immune system - SIS, which performs an important function in the defense of the body. Its proper operation protects the body against various external pathogens, eliminates virus-infected cells and cancer cells. Vitamin C deficiency resulting from improper diet or severe consumption in the course of a disease can manifest itself by: disturbances in the production of collagen and the consequent increase in bone fragility, slower wound healing, capillary fragility, the possibility of microhemorrhages formation in various organs, reduced resistance to infections, myalgia and fa- 
tigue, apathy and lack of appetite, occurrence of scurvy, manifested by swelling and bleeding of the gums and teeth falling out $[35,49]$.

\section{Carotenoids, retinoids}

Free radicals under the influence of oxidative stress, which is induced by the effect of ROS activity, damage the structure and functioning of nucleic acids, lipids, proteins and carbohydrates. Consequently, this process can lead to mutations and such diseases as cancer, cardiovascular, respiratory, certain diseases of the eye and may speed up the aging process of the body [50]. To defense itself against ROS the body uses its own antioxidant system (enzymes, endogenous antioxidants), as well as antioxidants consumed in diet. The natural antioxidants, which are to be provided with daily food, are carotenoids [51, 52]. These are widespread polyene vegetable dyes, which - apart from chlorophyll and anthocyanins - a group of the most important and the most frequently occurring pigments in nature. Humans and animals do not have the ability to synthesize carotenoids de novo and carotenoids must therefore be delivered to the human organism with food or in the form of pharmaceutical preparations [51-54]. Currently, there are numerous preparations containing carotenoids and their number is steadily increasing. Until 2002, in Poland there were available preparations containing only $\beta$-carotene, to a large extent designed to protect the skin from UV rays. There was no registered preparation containing lutein, zeaxanthin, astaxanthin or lycopene [51]. On a large scale, such preparations appeared worldwide in the early 90 s. Analysis of the market in terms of availability of preparations containing lutein and zeaxanthin conducted in 2006-2007 demonstrated the presence of about 50 preparations containing lutein, in that 12 also containing zeaxanthin [55]. At present, there exist more than twice more. The increasing popularity and use of carotenoids in pharmaceutical medicaments and the growing interest in their use in the prevention and treatment of diseases requires turning our attention to the dosage from the point of view of safety. The only documented side effect of high doses of supplements containing carotenoids was reversible hyperpigmentation of the skin. The Institute of Medicine of the National Academy of Science in the United States, however, recognized this condition as a minor biological effect of a high intake of carotenoids, reversible upon discontinuation of their use [56]. Despite the enormous interest in carotenoids, as well as the observed increase in the public consumption of dietary supplements and products enhanced with these compounds, no norms of daily demand have been established $[57,58]$. Under certain conditions, high doses of carotenoids, exceeding several times the usual intake in diet (for example at a high partial pressure of oxygen in cells) may have a prooxidative effect, being the promoters of free radicals formation. Furthermore, the products of oxidation of $\beta$-carotene may interfere with the transmission of signals and activate the cytochrome P450 enzymes and, thereby, promote tumor creation processes. Based on previous studies, it is not advised for cigarette smokers and asbestos-exposed people to use high doses of carotenoids, particularly $\beta$-carotene originating from supplements [50].

The fat soluble retinoids penetrate well into the stratum corneum, but to a small extent into the dermis. They accelerate the renewal of epidermis, exhibit a normalizing effect in keratinocyte differentiation processes and affect the control functions of the skin [59]. Retinoids affect processes such as protein synthesis, cell metabolism and cell division. In epidermis, retinoids may affect the secretion of transcription factors and growth factors. They are responsible for the proliferation of cells in the Malpighian layer of epidermis and stratum corneum exfoliation. The results of improving the structure of the stratum corneum are strengthening the protective function of the skin and reducing transepidermal water loss [57]. Retinoids increase the production of collagen and elastin in the layers of the skin. They stimulate the reaction of low activity fibroblast transformation into a cell characterized by a relatively high production of collagen. The growth in the number and activity of fibroblasts has a positive effect on the state of dermis, improving firmness, elasticity and hydration of the skin [61].

\section{Unsaturated fatty acids}

Omega-3 fatty acids found in fish oil and meat (mackerel, shark, salmon) and omega- 6 fatty acids derived from stone plants (flaxseed oil and blackcurrant seed oil, grapes, pumpkins) are a valuable nutrient for the skin. They play two major roles in the body: provide appropriate structure, flexibility and functioning of cell membranes and are essential for the synthesis of intracellular lipids in stratum corneum. Being the precursors of eicosanoids (prostaglandins, leukotrienes, thromboxanes), they also have regulatory properties [62].

A particularly interesting type of fish oil is shark oil. In addition to omega-3 essential fatty acids, which constitute only $5 \%$ of the product, it contains a large amount of alkylglycerols and squalene. It has been used by fishermen in Sweden and Norway for the treatment of wounds, respiratory and gastrointestinal infections, and lymphadenopathy. While the compounds of polyunsaturated fatty acids omega-3 have the properties of limiting inflammation, compounds of squalene and alkylglycerols aggravate the proinflammatory response by activating some elements of the immune system [63]. Squalene is a polyunsaturated aliphatic hydrocarbon widespread in nature. It serves as a precursor in the synthesis of cholesterol, vitamin D and steroid hormones, as well as exhibits strong antioxidant activity due to the contents of 
six isoprene units (vitamin A and coenzyme Q10 contain 1 and 2 of this unit). It is synthesized de novo in humans from acetyl-CoA in the process leading to the synthesis of cholesterol. In large quantities, it may be found in shark liver oil and other fish oils. In small amounts, it may be found in olive oil, wheat germ oil, or in yeast. It has been proven that squalene supports the immune system, affecting the cells and tissues responsible for immunity, for example, lymph nodes, bone marrow, adrenal glands, and liver. Moreover, it also increases the activity of T-lymphocytes and macrophages and accelerates wound healing. Squalene's immunomodulatory activity is probably a result its adherent properties with respect to cell membranes' elements and lipid casings of pathogens [64-66].

Clinical trials have demonstrated unquestionable effectiveness of preparations containing unsaturated fatty acids in enhancing both innate and acquired immunity, accelerating healing of recurrent aphthous ulcers and bacterial infections, and supporting the treatment of psoriasis $[63,67]$. By stimulating the immune system, they reduce the risk of allergic diseases and cancer, as well as support the treatment of rheumatoid arthritis, acne and atopic dermatitis [68, 69]. After application of fish oils rich in omega-3 acids in doses of $1 \mathrm{~g} /$ day for 30 days inhabitation of neutrophils, monocytes, and lymphocytes function followed. As a result, weakening the immune reactions and reduction of the inflammatory mediators' production was recognized. Supplementation of these preparations has led to decreasing the concentration levels of arachidonic acid and increasing the concentration of eicosapentaenoic and docosahexaenoic acids. In turn, it has limited the production of pro-inflammatory eicosanoids and increased the amount of eicosapentaenoic acid transformation products, which have a significantly lower biological activity than their analogues synthesized from arachidonic acid [70-72]. Furthermore, there is also inhibition of pro-inflammatory cytokines (e.g. IL-2, IL-6, IL-8, IL-12) with a negligible impact on cytokines which limit inflammation (IL-10). It is worth noting that the treatment with the use of fish oils does not cause side effects [71]. The proven effect of protection against both bacterial and fungal infections makes it advisable to use this medicament in patients with atopic dermatitis, who are particularly susceptible to such infections because of dry and impaired epidermal coetaneous barrier. Preliminary conclusions justify the inclusion of supplementation of fish and plant oils in patients with atopic dermatitis as an adjuvant to standard procedure [73].

\section{Conclusions}

The best source of vitamins and micro- and macronutrients affecting the skin, hair and nails, is a properly balanced diet. However, the development of food science, emergence of entirely new food products enriched with selected nutrients and dietary supplements allows us to take care of the body's needs in a healthy way. Therefore, supplements are becoming increasingly important in the prevention and supporting therapies of many diseases. It is worth monitoring and keeping a vigilant eye on this new and very rapidly developing food and pharmaceutical industry.

\section{Acknowledgments}

The work was done at the Department and Clinic of Gynecology and Gynecological Endocrinology, Medical University of Lublin.

\section{Conflict of interest}

All authors declare no conflict of interest.

\section{References}

1. Stoś K, Szponar L, Bogusz W, et al. Suplementy diety jako źródło składników o działaniu odżywczym i innym fizjologicznym [Polish]. Żyw Człow Metabol 2007; 34: 1036-40.

2. Nowak A, Śliżewska K, Libudzisz Z, Socha J. Probiotyki efekty zdrowotne [Polish]. ŻYWNOŚć Nauka, Technologia, Jakość 2010; 4: 20-36.

3. Dal'Belo SE, Gaspar LR, Maia Campos PM. Moisturizing effect of cosmetic formulations containing Aloe vera extract in different concentrations assessed by skin bioengineering techniques. Skin Res Technol 2006; 12: 241-6.

4. Bojarowicz H, Płowiec A. Wpływ witaminy A na kondycję skóry [Polish]. Probl Hig Epidemiol 2010; 91: 352-6.

5. Lewkowicz M, Lewkowicz P, Kurnatowska A, et al. Mechanizm działania i zastosowanie kliniczne oleju z wątroby rekina [Polish]. Pol Merk Lek 2006; 119: 598-601.

6. Rutkowski M, Grzegorczyk K. Witaminy o działaniu antyoksydacyjnym - ogólna charakterystyka [Polish]. Część III: Witamina C. Farm Pol 1999; 55: 74-9.

7. Allison A. Squalene and squalene emulsions as adjuvants. Methods Enzymol 1999; 19: 87-93.

8. Maienschein V. Nastolatki jako grupa celowa, trendy w kosmetykach dla generacji Internetu [Polish]. SOFW-Journal Wydanie Polskie 2008; 1: 27-9.

9. Gollnick H, Cunliffe W, Berson D, et al. Management of acne: a report from a global alliance to improve outcomes in acne. J Am Acad Dermatol 2003; 49: 1-37.

10. Hamutka J, Nogal D. Ocena oraz charakterystyka suplementów diety zawierających luteinę i zeaksantynę obecnych na polskim rynku farmaceutycznym [Polish]. Roczn PZH 2008; 59: 47-57.

11. Baber R. Phytoestrogens and post reproductive health. Maturitas 2010; 66: 344-9.

12. Saluk-Juszczak J. Antocyjany jako składniki żywności funkcjonalnej stosowanej w profilaktyce chorób układu krążenia [Polish]. Postepy Hig Med Dosw 2010; 64: 451-8.

13. Boelsma E, Hendriks F, Rosa L. Nutritional skin care: health effects of micronutritients and fatty acids. Am Clin Nutr 2001; 73: 853-64.

14. Dietary reference intakes for vitamin C, vitamin E, selenium and carotenoids. Food Nutrition Board. Institute of Medicine. Natl Acad Press, Washington DC, 2000.

15. Varani J, Warner RL, Gharaee-Kermani M, et al. Vitamin A antagonizes decreased cell growth and elevated collagen 
degrading matrix metaloproteinases and stimulates collagen accumulation in naturally aged human skin. J Invest Dermatol 2000; 114: 480-6.

16. Szponar L, Stoś K, Ołtarzewski M. Suplementy diety - możliwości ich wykorzystania w prewencji wybranych niedoborów żywieniowych [Polish]. Żyw Człow Metab 2004; 31 suppl. ı: 441-6.

17. Sikora M. Suplementy diety - wymóg dnia codziennego? [Polish]. Chem Rev 2009; 10: 40-3.

18. Shao A, Hathcock JN. Risk assessmant for the carotenoids lu tein and lycopene. Regul Toxicol Pharmacol 2006; 45: 289-98.

19. Szostak WB, Szostak-Węgierek D. Właściwości zdrowotne oleju z rekina [Polish]. Przegl Lek 2006; 63: 223-6.

20. Wartanowicz M, Ziemlański Ś. Stres oksydacyjny oraz mechanizmy obronne [Polish]. Żyw Człow Metab 1999; 26: 67-86.

21. Zając M, Pawełczyk E, Jelińska A. Chemia leków [Polish] Wydawnictwo Naukowe Akademii Medycznej w Poznaniu, Poznań 2006.

22. Bojarowicz H, Dźwigulska P. Suplementy diety. Część II. Wybrane składniki suplementów diety oraz ich przeznaczenie [Polish]. Hygeia Public Health 2012; 47: 433-41.

23. Kamer B, Pasowska R, Dółka E, et al. Prevalence of atopic dermatitis in infants during the first six months of life: authors' observations. Postep Derm Alergol 2013; 29: 277-81.

24. Majamaa H, Isolauri E. Probiotics: a novel approach in the management of food allergy. J Allergy Clin Immunol 1997; 99: 179-85.

25. Mayne ST. Antioxidant nutrients and chronic disease. J Nutr 2003; 133: 933-40.

26. Puzanowska-Tarasiewicz H, Kuźmicka L, Tarasiewicz M. Biological function of some elements and their compounds. IV. Silicon, silicon acids, silicones. Pol Merkur Lek 2009; 27: 423-6.

27. Rodríguez RE, Darias MJ, Díaz RC. Aloe vera as a functional ingredient in foods. Crit Rev Food Sci Nutr 2010; 50: 305-26.

28. Gawęcki J. Podstawowe składniki pożywienia. In: Kompendium wiedzy o żywności, żywieniu i zdrowiu [Polish]. Gawęcki J, Mossor-Pietraszewska T (ed.). Wydawnictwo Naukowe PWN, Warsaw 2006; 238-44.

29. Bobrowska B, Olędzka R. Współczesne poglądy na rolę żywieniową luteiny i likopenu [Polish]. Bromat Chem Toksykol 2002; 35: 289-96.

30. Commission staff working document "Characteristics and perspectives of the market for food supplements containing substances other than vitamins and minerals" - Bruksela, 5.12.2008 SEC (2008) 2976.

31. Szkutnik-Fiedler D, Jędrzejczyk M, Grześkowiak E, et al. The role of phytoestrogen therapy in relieving postmenopausa symptoms. Ginekol Pol 2010; 81: 929-34.

32. Jopp A. Ryzyko braku witamin [Polish]. Interspar, Warsaw 2006; 123-5.

33. Stoś K, Bogusz-Kaliś W. Rodzaje suplementów diety. In Suplementy diety a zdrowie. Porady lekarzy i dietetyków [Polish]. Jarosz M (ed.). PZWL, Warsaw 2011; 15-24.

34. Muta-Takada K, Terada T, Yamanishi H, et al. Coenzyme Q protects against oxidative stress-induced cell death and enhancesthe synthesis of basementmembrane componentsin dermal and epidermal cells. Biofactors 2009; 35: 435-41.

35. Hamułka J, Wawrzyniak A. Karotenoidy w suplementach diety [Polish]. Probl Hig Epidemiol 2011; 92: 67-72.

36. Krasnowska G, Sikora T. Suplementy diety a bezpieczeństwo konsumenta [Polish]. ŻYWNOŚć. Nauka, Technologia, Jakość 2011; 4: 77: 5-23.

37. Krejpcio Z, Skwarek K, Hyżyk AK, Dyba S. Ocena powszechności spożycia suplementów diety w wybranej grupie osób aktywnych sportowo [Polish]. Probl Hig Epidemiol 2011; 92 : 935-8.

38. Kaliomaki M, Salminen S, Poussa T, et al. Probiotics and prevention of atopic disease: 4-year follow-up of randomized placebo - controlled trial. Lancet 2003; 361: 1869-71.

39. Rutkowski M, Grzegorczyk K, Chojnacki J, et al. Właściwości antyoksydacyjne witaminy E podstawa jej nowych zastosowań w terapii [Polish]. Pol Merk Lek 2006; 20: 609-14.

40. O’Neill ME, Carroll Y, Corridan B, et al. A European carotenoid database to assess carotenoid intakes and its use in a five-country comparative study. Br J Nutr 2001; 85: 499-507.

41. Chamras H, Ardashian A, Heber D, et al. Fatty acid modulation of MCF-7 human breast cancer cell proliferation, apoptosis and differentiation. J Nutr Biochem 2002; 13: 711-6.

42. Nkondjock A, Shatenstein B, Maisonneuve P, Ghadirian P. Specific fatty acids and human colorectal cancer: an overview. Cancer Detect Prev 2003; 27: 55-66.

43. Lewkowicz P, Lewkowicz N, Tchórzewski H. Rola alkilogliceroli, skwalenu i wielonienasyconych kwasów omega 3 w zwalczaniu infekcji bakteryjnych - modyfikacja naturalnych (wrodzonych) mechanizmów odporności [Polish]. Problemy Ter Mon 2002; 13: 163-9.

44. Duda G, Saran A. Preparaty witaminowo-mineralne przeznaczone dla osób w starszym wieku [Polish]. Gerontol Pol 2009; 17: 106-13.

45. Kleszczewska E. Biologiczne znaczenie witaminy C ze szczególnym uwzględnieniem jej znaczenia w metabolizmie skóry [Polish]. Pol Merk Lek 2007; 23: 462-5.

46. Krinsky NI, Johnson EJ. Carotenoid actions and their relation to health and disease. Mol Asp Med 2005; 26: 459-516.

47. Nowicki R, Barańska-Rybak W. Olej z wątroby rekina jako terapia wspomagająca $w$ atopowym zapaleniu skóry [Polish]. Pol Merk Lek 2007; 22: 312-3.

48. Rutkowski R, Rutkowski K, Rutkowska-Talipska J, et al. Vitamin C: is it time to re-evaluate its role in health and disease? Postep Derm Alergol 2012; 29: 456-60.

49. Cho S, Lee S, Lee MJ, et al. Dietary Aloe vera supplementation improves facial wrinkles and elasticity and it increases the type I procollagen gene expression in human skin in vivo. Ann Dermatol 2009; 21: 6-11.

50. Isolauri E, Arvola T, Sutas Y, et al. Probiotics in the management of atopic eczema. Clin Exp Allergy 2000; 30: 1604-10.

51. Ustawa z dnia 25 sierpnia 2006 r. o bezpieczeństwie żywności i żywienia. Dz. U. 2006r. Nr 171, poz.1225, z późn. zm., art. 3.

52. Cooke A, Cooked MD. An investigation into the antimicrobial properties of Manuka and Kanuka oil. Cawthron Report No. 263, New Zealand 1994

53. Racek J, Holecek V, Trefil L. Antioxidative properties of ascorbic acid. Cas Lek Cesk 2000; 139: 583-7.

54. Kmieć ML, Pajor A, Broniarczyk-Dyła G. Evaluation of biophysical skin parameters and assessment of hair growth in patients with acne treated with isotretinoin. Postep Derm Alergol 2013; 30: 343-9.

55. Cukrowska B, Ceregra A, Rosiak I. Probiotyki w profilaktyce i leczeniu atopowego zapalenia skóry [Polish]. Zakażenia 2006; 2: 58-61.

56. Jarosz M, Bułhak-Jachymczyk B. Normy żywienia człowieka. Podstawy prewencji otyłości i chorób niezakaźnych [Polish]. PZWL, Warsaw 2008

57. Saleh F, Afnan F, Ara F, et al. Phytoestrogenin take and cardiovascular risk markers in Bangladeshi postmenopausal women. Mymensingh Med J 2011; 20: 219-25.

58. Kaliomaki M, Salminen S, Arvilommi H, et al. Probiotics in primary prevention of atopic disease: a randomized placebo - controlled trial. Lancet 2001; 357: 1076-9. 
59. Kunachowicz H, Troszczyńska A. Żywność wzbogacana i suplementy witaminowo-mineralne a ich rola w prawidłowej diecie człowieka [Polish]. Now Lek 2005; 74: 533-8.

60. Sorg O, Kuenzli S, Kaya G, Saurat JH. Proposed mechanisms of action for retinoid derivatives in the treatment of skin aging. J Cosmetic Dermatol 2005; 4: 237-44.

61. Lewkowicz P, Banasik M, Głowacka E, et al. Modyfikujący wpływ dużych dawek preparatu oleju z wątroby rekina na polaryzację limfocytów T oraz funkcję neutrofili krwi [Polish]. Pol Merk Lek 2005; 108: 686-92.

62. Pietruszka B, Brzozowska A. Uwarunkowania suplementacji diety witaminami i składnikami mineralnymi w Polsce [Polish]. Żyw Człow Metab 2002; 29: 215-9.

63. Ahn YK, Kin JH. Effects of squalene on the immune response in mice (II). Cellular and non-specific immune response and antitumor activity of squalene. Arch Pharmacol Res 1992; 15: 20-9.

64. Cieślik E, Gębusia A. Skutki niedostatecznej podaży kwasu foliowego ze szczególnym uwzględnieniem znaczenia dla kobiet w wieku rozrodczym [Polish]. Hygeia Public Health 2011; 46: 431-6.

65. Górecka D, Czarnocińska J, Idzikowski M, Kowalec J. Postawy osób dorosłych wobec żywności funkcjonalnej w zależności od wieku i płci [Polish]. ŻYWNOŚć. Nauka, Technologia, Jakość 2009; 4: 320-6.

66. Stepulak M, Leleń K, Malejczyk M, et al. Biological activity of ceramides and other sphingolipids. Postep Derm Alergol 2012: 29: 169-75.

67. Naturalne antyoksydanty w farmacji i medycynie. Materiały sympozjum Wydziału Farmaceutycznego Akademii Medycznej, 2001. 27-28.04 Warszawa [Polish]. Farm Pol 2001; 57: 699-759.

68. Reguła J, Gramza-Michałowska A, Stachowiak B. Udział suplementów diety w żywieniu osób dorosłych [Polish]. Probl Hig Epidemiol 2011; 92: 614-6.

69. Weise Prinzo Z, de Benoist B. Meeting the challenges of micronutrient deficiencies in emergency - affected populations. Proc Nutr Soc 2002; 61: 251-7.

70. Rutkowski M, Matuszewski T, Kędziora J, et al. Witaminy E, A i C jako antyoksydanty [Polish]. Pol Merk Lek 2010; 29: 377-81.

71. Bramley PM, Elmadfa I, Kafatos A, et al. Vitamin E - review. J Sci Food Agric 2000; 80: 913-38.

72. Wasiluk D, Stefanska E, Ostrowska L, et al. Nutritive value of daily food rations of patients with psoriasis vulgaris: a preliminary report. Postep Derm Alergol 2012; 29: 348-55.

73. Christen WG, Gaziano JM, Hennekens CH. Design of physicians' Health Study $\mathrm{II}$ - a randomized trial of beta-carotene, vitamins $E$ and $C$, and multivitamins, in prevention of cancer, cardiovascular disease, and eye disease, and review of results of completed trials. Ann Epidemiol 2000; 10: 125-34. 